Article

\title{
Synthesis, Antiproliferative Activity and Molecular Properties Predictions of Galloyl Derivatives
}

\section{Marciane Maximo da Silva ${ }^{1}$, Marina Comin ${ }^{2}$, Thiago Santos Duarte ${ }^{2}$, Mary Ann Foglio ${ }^{3}$, João Ernesto de Carvalho ${ }^{3}$, Maria do Carmo Vieira ${ }^{4}$ and Anelise Samara Nazari Formagio ${ }^{4, *}$}

1 Faculdade de Ciências Biológicas e Ambientais, Universidade Federal da Grande Dourados, Rodovia Dourados-Itahum, Km 12, Dourados, 79.804-970 MS, Brazil;

E-Mail: marcianemaximo@hotmail.com

2 Faculdade de Ciências Exatas e Tecnologia, Universidade Federal da Grande Dourados, Rodovia Dourados-Itahum, Km 12, Dourados, 79.804-970 MS, Brazil;

E-Mails: marina_comin@hotmail.com (M.C.); thiagosantos948@gmail.com (T.S.D.)

3 Centro Pluridisciplinar de Pesquisas Químicas, Biológicas e Agrícolas, Universidade Estadual de Campinas, 6171, Campinas, 13083-970 SP, Brazil;

E-Mails: foglioma@cpqba.unicamp.br (M.A.F.); carvalho_je@yahoo.com.br (J.E.C.)

4 Faculdade de Ciências Agrárias, Universidade Federal da Grande Dourados, Rodovia Dourados-Itahum, Km 12, Dourados, 79.804-970 MS, Brazil;

E-Mail: mariavieira@ufgd.edu.br

* Author to whom correspondence should be addressed; E-Mail: aneliseformagio@ufgd.edu.br; Tel.: +55-67-3410-2426.

Academic Editor: Panayiotis A. Koutentis

Received: 11 November 2014 / Accepted: 9 March 2015 / Published: 25 March 2015

\begin{abstract}
The present study was designed to investigate the in vitro antiproliferative activity against ten human cancer cell lines of a series of galloyl derivatives bearing substituted-1,3,4-oxadiazole and carbohydrazide moieties. The compounds were also assessed in an in silico study of the absorption, distribution, metabolism and excretion (ADME) in the human body using Lipinski's parameters, the topological polar surface area (TPSA) and percentage of absorption (\%ABS). In general, the introduction of $N^{\prime}$-(substituted)-arylidene galloyl hydrazides 4-8 showed a moderate antitumor activity, while the 2-methylthio- and 2-thioxo-1,3,4-oxadiazol-5-yl derivatives $\mathbf{9}$ and $\mathbf{1 0}$ led to increased inhibition of cancer cell proliferation. The precursor compound methyl gallate $\mathbf{2}$ and the intermediary galloyl hydrazide $\mathbf{3}$ showed greater antiproliferative activity with GI50
\end{abstract}


values $<5.54 \mu \mathrm{M}$ against all human tumor cell lines tested. A higher inhibition effect against ovarian cancer (OVCAR-3) $\left(\mathrm{GI}_{50}=0.05-5.98 \mu \mathrm{M}\right)$ was also shown, with compounds 2, 3, 9 and $\mathbf{1 0}$ with $\mathrm{GI}_{50} \leq 0.89 \mu \mathrm{M}$ standing out in this respect. The in silico study revealed that the compounds showed good intestinal absorption.

Keywords: galloyl; hydrazide; oxadiazole; antiproliferative activity; in silico study

\section{Introduction}

Gallic acid (3,4,5-trihydroxybenzoic acid) is a polyphenol that possesses a wide spectrum of important pharmacological properties. In particular, gallic acid affects several pharmacological and biochemical pathways and has strong antioxidant [1,2], anti-inflammatory [3], antimutagenic and anticancer properties [4-6], showing selective cytotoxicity against a variety of tumor cells and much less toxicity against normal cells [7-15].

Studies with a variety of synthetic galloyl derivatives have demonstrated the influence of substituents on cytotoxic activity, e.g., digalloylresveratrol shows induction of apoptosis and necrosis in HT-29 colon cancer cells and HL-60 human promyelocytic leukemia cells, and gallic acid esters show inhibition of cancer cell proliferation [14,16-23]. Appropriate substituents in the galloyl group positions could lead to more potent compounds.

The isolation of methyl gallate from the methanol extract of Schinus terebinthifolius leaves by our research group (data not shown) and the biological potential of the galloyl group directed us to develop derivatives as antitumor agents. Mannich bases of oxadiazoles and carbohydrazides possess important activities, including anticancer functions [24-27] and our prior studies showed that introducing 1,3,4-oxadiazole and carbohydrazide units at the $\mathrm{C}-3$ position of the $\beta$-carboline derivatives led to significant antitumor action [28-30]. As such, we proposed the synthesis and in vitro antiproliferative activity evaluation of a series of galloyl derivatives bearing the substituted-1,3,4-oxadiazole and carbohydrazide moiety at position $\mathrm{C}-1$, expecting that the incorporation of these substituent may improve the antitumor activities of the galloyl group. Herein, the synthesis of 2-methylthio- and 2-thioxo-1,3,4-oxadiazol-5-yl derivatives is reported for the first time. Additionally, an in silico study of the absorption, distribution, metabolism, and excretion (ADME) properties of the compounds was performed by investigating their match of Lipinski's rules, topological polar surface area (TPSA) and percentage of absorption (\%ABS). In silico ADME is currently used widely to determine whether it is possible for a drug candidate to reach its site of action.

\section{Results and Discussion}

\subsection{Chemistry}

The synthetic route for the preparation of the galloyl derivatives is presented in Scheme 1. Methyl gallate (2) was prepared by esterification of the corresponding carboxylic acid $\mathbf{1}$ with methanol and sulfuric acid [31]. The reaction of methyl gallate with hydrazine hydrate yielded the galloyl hydrazide 3 . Condensation of the hydrazide $\mathbf{3}$ with aromatic aldehydes (benzaldehyde, 4-dimethylaminobenzaldehyde, 
4-nitrobenzaldehyde, 4-methoxybenzaldehyde and 4-hydroxybenzaldehyde), in ethanol heated at reflux, yielded the $N^{\prime}$-(substituted)-arylidenegalloyl hydrazides $4-8$, respectively. The IR and ${ }^{1} \mathrm{H}-\mathrm{NMR}$ spectroscopic data of these compounds were consistent with the related literature and the experimental conditions and yields for the reaction were satisfactory [32].

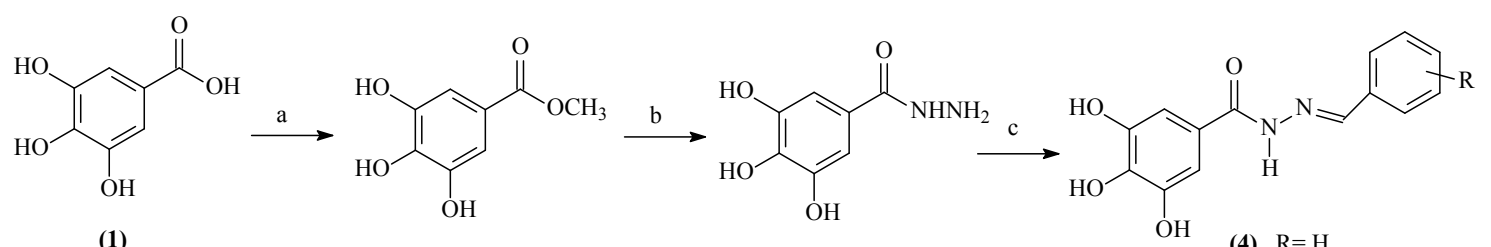

(1)

(2)

(3)

(5) $\mathrm{R}=4-\mathrm{N}\left(\mathrm{CH}_{3}\right)_{2}$

(6) $\mathrm{R}=4-\mathrm{NO}_{2}$

(7) $\mathrm{R}=4-\mathrm{OCH}_{3}$

(8) $\mathrm{R}=4-\mathrm{OH}$

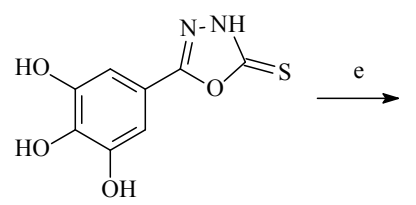

(9)

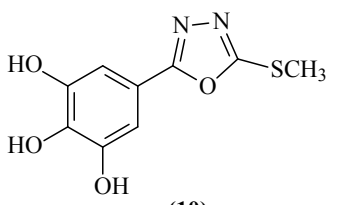

(10)

Reagents and conditions: (a) $\mathrm{MeOH}, \mathrm{H}_{2} \mathrm{SO}_{4}$, reflux, $48 \mathrm{~h} ; 85 \%$; (b) $\mathrm{NH}_{2} \mathrm{NH}_{2} \cdot \mathrm{H}_{2} \mathrm{O}$, EtOH, reflux, $48 \mathrm{~h}$; 74\%; (c) RCHO, EtOH, $\mathrm{H}_{2} \mathrm{SO}_{4}$ (cat), reflux, 36 h; 74\%-80\%; (d) $\mathrm{CS}_{2} / \mathrm{KOH}$, EtOH, reflux, $48 \mathrm{~h}$, acidified dilute $\mathrm{HCl}$; (e) MeI, $\mathrm{K}_{2} \mathrm{CO}_{3}$, THF, rt, $48 \mathrm{~h}$.

Scheme 1. Synthetic route for the preparation of the galloyl derivatives.

For preparation of new derivatives of galloyl-2-thioxo-1,3,4-oxadiazole (9), the key intermediate 3 was subjected to a reaction with carbon disulfide in the presence of $\mathrm{KOH}$ and ethanol heated at reflux. The 1,3,4-oxadiazolyl 9 was subsequently S-methylated with methyl iodide in the presence of $\mathrm{K}_{2} \mathrm{CO}_{3}$ at room temperature to yield afford the galloyl-2-methylthio-1,3,4-oxadiazole $\mathbf{1 0}$.

The chemical structures of all compounds were confirmed by spectral data $\left({ }^{1} \mathrm{H}-\right.$ and ${ }^{13} \mathrm{C}-\mathrm{NMR}, \mathrm{IR}$, and MS) (see Section 3). The ${ }^{1} \mathrm{H}-\mathrm{NMR}$ spectra of $N^{\prime}$-(substituted)-arylidene galloyl hydrazides 4-8 displayed signals at $\delta_{\mathrm{H}} 8.40 \mathrm{ppm}$ integrating for one proton and $\delta_{\mathrm{H}} 6.70-9.00 \mathrm{ppm}$, corresponding to the imine and aromatic hydrogens, respectively, of the (substituted-benzylidene) galloyl hydrazide group. The presence of this group was confirmed by the signals at $\delta_{\mathrm{C}} 147-150(\mathrm{C}=\mathrm{N}), 158-162(\mathrm{C}=\mathrm{O})$, and 110-135 ppm (aromatic carbons of R group) in the ${ }^{13} \mathrm{C}-\mathrm{NMR}$ spectra.

The galloyl-2-thioxo-1,3,4-oxadiazole 9 may exist in a thione-thiol tautomeric structure, as indicated by the $-\mathrm{NH}$ and $-\mathrm{SH}$ proton signals at $13.7-14.1 \mathrm{ppm}$ in the ${ }^{1} \mathrm{H}-\mathrm{NMR}$ spectrum, as a broad singlet integrating for one hydrogen each. In the solid state, these compounds are present in the thione $(\mathrm{C}=\mathrm{S})$ form, as indicated in their IR spectrum by the absence of the $v_{\mathrm{s}}(\mathrm{S}-\mathrm{H})$ absorption band at $2500 \mathrm{~cm}^{-1}$ and the presence of two $v(\mathrm{C}=\mathrm{S})$ absorption bands at $1230-1339 \mathrm{~cm}^{-1}$, which is characteristic for this class of compounds. The S-methylated derivative $\mathbf{1 0}$ was characterized by the presence of an addition signal at $\delta_{\mathrm{H}} / \delta_{\mathrm{C}} 2.84 / 14.7 \mathrm{ppm}$, corresponding to the S-methyl group attached to the oxadiazole nucleus. 


\subsection{Antiproliferative Activity}

Three response parameters $\left(\mathrm{GI}_{50}, \mathrm{TGI}\right.$, and $\mathrm{LC}_{50}$ ) were calculated for each compound and cell line, and the results are summarized in Tables 1 and 2.

Table 1. GI50 values $(\mu \mathrm{M})$ for compounds $\mathbf{2}-\mathbf{1 0}$ in ten tumor cell lines.

\begin{tabular}{ccccccccccc}
\hline \multicolumn{10}{c}{ Cancer Cell Lines } \\
\hline & U251 & MCF-7 & NCI/ADR-RES & $\mathbf{7 8 6 - 0}$ & NCI-H460 & PC-3 & OVCAR-3 & HT-29 & K-562 & HaCaT \\
\hline $\mathbf{2}$ & 0.16 & 0.16 & 0.12 & 0.65 & 0.13 & 0.57 & 0.05 & 0.49 & 0.31 & 0.26 \\
$\mathbf{3}$ & 1.11 & 0.85 & 0.91 & 1.56 & 5.54 & 3.53 & 0.88 & 1.21 & 1.17 & 2.50 \\
$\mathbf{4}$ & 7.80 & 5.55 & 7.16 & 9.06 & 11.20 & 5.07 & 1.24 & 7.53 & 9.96 & 8.29 \\
$\mathbf{5}$ & 24.10 & 8.61 & 4.68 & 8.93 & 21.64 & - & 2.93 & 16.24 & 2.05 & 4.05 \\
$\mathbf{6}$ & 5.12 & - & 8.46 & 7.60 & - & 13.99 & 5.91 & - & - & 31.55 \\
$\mathbf{7}$ & 9.14 & 15.66 & 11.34 & 18.85 & 41.05 & 19.64 & 5.98 & 25.12 & 8.93 & 18.08 \\
$\mathbf{8}$ & 6.60 & - & - & 26.80 & 9.38 & - & 1.35 & - & 9.17 & 8.72 \\
$\mathbf{9}$ & 4.20 & 1.08 & 2.83 & 8.90 & 8.77 & 6.05 & 0.89 & 2.61 & 1.72 & 2.25 \\
$\mathbf{1 0}$ & 5.20 & 0.34 & 0.17 & 9.20 & 9.44 & 7.43 & 0.14 & 2.77 & 0.60 & 2.50 \\
Dox & 0.02 & 0.01 & 0.20 & 0.04 & 0.01 & 0.18 & 0.02 & 0.09 & 0.03 & 0.01 \\
\hline
\end{tabular}

$\mathrm{GI}_{50}$ : (growth inhibitory activity) the drug concentration that reduces cellular growth by $50 \%$; Dox:

Doxorubicin; (-): $\mathrm{GI}_{50}$ value not presented.

Table 2. TGI and $\mathrm{LC}_{50}$ (values in parentheses) in $\mu \mathrm{g} / \mathrm{mL}$ for compounds $\mathbf{2}-\mathbf{1 0}$ in ten tumor cell lines.

\begin{tabular}{|c|c|c|c|c|c|c|c|c|c|c|}
\hline \multicolumn{11}{|c|}{ Cancer Cell Lines } \\
\hline & $\mathrm{U} 251$ & MCF-7 & NCI/ADR-RES & 786-0 & NCI-H460 & PC-3 & OVCAR-3 & HT-29 & K-562 & HaCaT \\
\hline 2 & $\begin{array}{c}4.10 \\
(29.19) \\
\end{array}$ & $\begin{array}{c}5.12 \\
(-) \\
\end{array}$ & $\begin{array}{c}3.62 \\
(30.26) \\
\end{array}$ & $\begin{array}{c}8.62 \\
(31.36) \\
\end{array}$ & $\begin{array}{c}7.97 \\
(34.92) \\
\end{array}$ & $\begin{array}{c}13.10 \\
(-) \\
\end{array}$ & $\begin{array}{c}1.59 \\
(33.69) \\
\end{array}$ & $\begin{array}{c}8.52 \\
(30.60) \\
\end{array}$ & $\begin{array}{c}5.67 \\
(-) \\
\end{array}$ & $\begin{array}{c}16.74 \\
(-) \\
\end{array}$ \\
\hline 3 & $\begin{array}{c}6.13 \\
(31.36) \\
\end{array}$ & $\begin{array}{c}2.36 \\
(-)\end{array}$ & $\begin{array}{c}2.56 \\
(-) \\
\end{array}$ & $\begin{array}{c}17.98 \\
(-)\end{array}$ & $\begin{array}{c}17.35 \\
(-)\end{array}$ & $\begin{array}{c}18.31 \\
(-)\end{array}$ & $\begin{array}{c}9.77 \\
(-) \\
\end{array}$ & $\begin{array}{c}3.27 \\
(26.21) \\
\end{array}$ & $\begin{array}{l}- \\
-\end{array}$ & $\begin{array}{l}29.02 \\
>100\end{array}$ \\
\hline 4 & - & $\begin{array}{c}23.54 \\
(-)\end{array}$ & - & - & - & - & $\begin{array}{c}29.61 \\
(-)\end{array}$ & - & - & - \\
\hline 5 & - & $\begin{array}{r}20.26 \\
(47.93) \\
\end{array}$ & $\begin{array}{c}83.07 \\
(-)\end{array}$ & - & - & - & $\begin{array}{c}41.52 \\
(-)\end{array}$ & $\begin{array}{c}48.50 \\
(-)\end{array}$ & $\begin{array}{c}8.98 \\
(-)\end{array}$ & $\begin{array}{r}18.41 \\
(55.32) \\
\end{array}$ \\
\hline 6 & - & - & - & - & - & $\begin{array}{c}84.67 \\
(-)\end{array}$ & - & - & - & - \\
\hline 7 & $\begin{array}{c}64.22 \\
(-)\end{array}$ & - & $\begin{array}{c}66.56 \\
(-)\end{array}$ & - & - & - & - & - & $\begin{array}{c}41.76 \\
(-)\end{array}$ & - \\
\hline 8 & $\begin{array}{c}26.07 \\
(-)\end{array}$ & - & - & - & - & - & - & - & - & - \\
\hline 9 & $\begin{array}{c}14.58 \\
(41.26) \\
\end{array}$ & $\begin{array}{c}5.06 \\
(-) \\
\end{array}$ & $\begin{array}{c}15.86 \\
(-)\end{array}$ & $\begin{array}{c}24.68 \\
(-)\end{array}$ & $\begin{array}{c}19.43 \\
(42.67) \\
\end{array}$ & $\begin{array}{c}18.09 \\
(56.99) \\
\end{array}$ & $\begin{array}{c}13.62 \\
(58.99) \\
\end{array}$ & $\begin{array}{c}13.74 \\
(58.99) \\
\end{array}$ & $\begin{array}{c}11.35 \\
(58.99) \\
\end{array}$ & $\begin{array}{c}16.53 \\
(-)\end{array}$ \\
\hline 10 & $\begin{array}{c}16.40 \\
(30.43) \\
\end{array}$ & $\begin{array}{c}3.20 \\
(20.24) \\
\end{array}$ & $\begin{array}{c}2.33 \\
(19.65) \\
\end{array}$ & $\begin{array}{c}29.40 \\
(-) \\
\end{array}$ & $\begin{array}{c}29.52 \\
(65.78) \\
\end{array}$ & $\begin{array}{c}28.45 \\
(69.30) \\
\end{array}$ & $\begin{array}{c}2.38 \\
(17.34) \\
\end{array}$ & $\begin{array}{c}17.66 \\
(60.32) \\
\end{array}$ & $\begin{array}{c}3.70 \\
(20.20) \\
\end{array}$ & $\begin{array}{c}18.00 \\
(-) \\
\end{array}$ \\
\hline Dox & $\begin{array}{c}2.68 \\
(-)\end{array}$ & $\begin{array}{c}2.52 \\
(-)\end{array}$ & $\begin{array}{c}22.42 \\
(-)\end{array}$ & $\begin{array}{c}0.51 \\
(17.82)\end{array}$ & $\begin{array}{c}3.73 \\
(-)\end{array}$ & $\begin{array}{c}1.03 \\
(7.95)\end{array}$ & $\begin{array}{c}1.47 \\
(-)\end{array}$ & $\begin{array}{c}26.03 \\
(-)\end{array}$ & $\begin{array}{c}2.60 \\
(20.09)\end{array}$ & $\begin{array}{c}0.77 \\
(-)\end{array}$ \\
\hline
\end{tabular}

TGI: the drug concentration required for total growth inhibition; $\mathrm{LC}_{50}$ : the drug concentration required for

killing 50\% of cells; Dox: Doxorubicin; (-): not presented. 
The GI50 values (growth inhibitory activity) (Table 1) refer to the drug concentration that produces a $50 \%$ reduction of cellular growth compared with the untreated control cells. The TGI (cytostatic activity) and $\mathrm{LC}_{50}$ (cytotoxic activity) values (Table 2) refer to the drug concentration required for total growth inhibition and killing $50 \%$ of the cells, respectively. GI50 values were used to classify a compound's activity as follows: inactive, $>100 \mu \mathrm{M}$; moderate, between $>10$ and $<100 \mu \mathrm{M}$; and active, $<10 \mu \mathrm{M}$.

The $N^{\prime}$-(substituted)-arylidene galloyl hydrazide 4, which has a phenyl group attached to the galloyl hydrazide moiety, possesses antiproliferative activity with GI50 values ranging from 1.24 to $9.96 \mu \mathrm{M}$ for nine human tumor cell lines. In particular, the compound displayed activity against the ovarian cell line OVCAR-3 with a GI50 value of $1.24 \mu \mathrm{M}$ (Table 1). Derivative 5, which has a dimethylaminophenyl group attached to the galloyl hydrazide moiety, displayed cytotoxic efficacy against OVCAR-3 $\left(\mathrm{GI}_{50}=2.93 \mu \mathrm{M}\right.$; TGI $\left.=41.52 \mu \mathrm{M}\right)$ and leukemia $\mathrm{K}-562\left(\mathrm{GI}_{50}=2.05 \mu \mathrm{M}\right.$; TGI $\left.=8.98 \mu \mathrm{M}\right)$ cell lines (Tables 1 and 2). Compounds 6 and 7 did not demonstrate cytotoxic efficacy in these cell lines. The activity against the OVCAR-3 cell line was also observed for compound $8\left(\mathrm{GI}_{50}=1.35 \mu \mathrm{M}\right)$, containing the $p$-hydroxyphenyl group to the galloyl hydrazide moiety.

The introduction of the 2-thioxo-1,3,4-oxadiazol-5-yl group 9 at C-1 of the galloyl group led to significant cytotoxicity, with $\mathrm{GI}_{50}$ less than $8.90 \mu \mathrm{M}$ towards all cell lines, and displayed significant activity against OVCAR-3 $\left(\mathrm{GI}_{50}=0.89 \mu \mathrm{M}\right), \mathrm{MCF}-7\left(\mathrm{GI}_{50}=1.08 \mu \mathrm{M}\right), \mathrm{K}-562\left(\mathrm{GI}_{50}=1.72 \mu \mathrm{M}\right)$, $\operatorname{HaCaT}\left(\mathrm{GI}_{50}=2.25 \mu \mathrm{M}\right), \mathrm{HT}-29\left(\mathrm{GI}_{50}=2.61 \mu \mathrm{M}\right)$, and NCI/ADR/RES $\left(\mathrm{GI}_{50}=2.83 \mu \mathrm{M}\right)$ cell lines. The 2-methylthio analogue $\mathbf{1 0}$ showed an increase in antiproliferative activity, with particular effectiveness against OVCAR-3 $\left(\mathrm{GI}_{50}=0.14 \mu \mathrm{M}\right.$, TGI $\left.=2.38 \mu \mathrm{M}, \mathrm{LC}_{50}=17.34 \mu \mathrm{M}\right), \mathrm{MCF}-7\left(\mathrm{GI}_{50}=0.34 \mu \mathrm{M}\right.$, $\left.\mathrm{TGI}=3.20 \mu \mathrm{M}, \mathrm{LC}_{50}=20.24 \mu \mathrm{M}\right), \mathrm{K}-562\left(\mathrm{GI}_{50}=0.60 \mu \mathrm{M}, \mathrm{TGI}=3.70 \mu \mathrm{M}, \mathrm{LC}_{50}=20.20 \mu \mathrm{M}\right)$ and $\mathrm{NCI} / \mathrm{ADR} / \mathrm{RES}\left(\mathrm{GI}_{50}=0.17 \mu \mathrm{M}, \mathrm{TGI}=2.33 \mu \mathrm{M}, \mathrm{LC}_{50}=19.65 \mu \mathrm{M}\right)$ cell line (Tables 1 and 2$)$.

In addition, the precursor compound methyl gallate 2 exhibited potent, broad-spectrum antitumor activity with $\mathrm{GI}_{50}$ values $<1.0 \mu \mathrm{M}$ against all human tumor cell lines tested, with GI50 (TGI) values ranging from 0.05 to $0.65 \mu \mathrm{M}(1.59-16.74 \mu \mathrm{M})$ (Tables 1 and 2). The intermediary, galloyl hydrazide 3, also showed significant activity, with $\mathrm{GI}_{50}$ values in the range of $0.85-5.54 \mu \mathrm{M}$ for all cell lines tested, and displayed cytotoxic efficacy against MCF-7 breast $\left(\mathrm{GI}_{50}=0.85 \mu \mathrm{M}\right.$, TGI $\left.=2.36 \mu \mathrm{M}\right)$, NCI/ADR-RES multiple drug resistant breast $\left(\mathrm{GI}_{50}=0.91 \mu \mathrm{M}\right.$, TGI $\left.=2.56 \mu \mathrm{M}\right)$ and OVCAR-3 ovarian $\left(\mathrm{GI}_{50}=0.88 \mu \mathrm{M}\right.$, TGI $\left.=9.77 \mu \mathrm{M}\right)$ cells (Tables 1 and 2$)$. Methyl gallate is a derivative of gallic acid that has been extensively investigated for important biological properties such as antioxidant, anti-inflammatory, antimicrobial and antitumor activities by inhibiting tumor infiltration of $\mathrm{CD}^{+} \mathrm{CD} 25^{+}$regulatory $\mathrm{T}$ cell and glioma cells [19,33-37]. However, the antitumor activity of this compound has not been extensively examined in other cancer cells. We examined the effect of methyl gallate in ten human tumor cell lines and observed selective cytotoxicity in all cell lines tested.

An analysis of the relationship between the GI50 data and the effects of the substitutions in the aromatic ring at the $N^{\prime}$-(substituted)-arylidene galloyl hydrazide with electron-withdrawing and electron-donating substituents 5-8 did not display enhanced activity compared with the phenyl substituent 4, which demonstrated a pronounced effect on cell line proliferation. These results suggest that the electronic features of the various substituents affect how easily the drug can interact with biological molecules. Regarding the relationship between the 1,3,4-oxadiazolyl derivatives, compound 10 displayed the highest antiproliferative activity compared to the corresponding precursor 9, 
exhibiting selectivity for four cell lines. Substitution by ester, hydrazine and 1,3,4-oxadiazolyl moiety side chains in compounds $\mathbf{2 , 3 , 9}$ and $\mathbf{1 0}$ resulted in a reduction in the percentage of growth inhibition, thereby indicating the importance of these side chain groups.

The anthracyclins doxorubicin (DOX) and daunorubicin (DNR) are among the most useful antibiotic, antitumor natural isolates from a species of the bacteria Streptomyces for the treatment of breast cancer, solid tumors and leukemia [38-42]. The mechanism of action is complex. Briefly, doxorubicin interferes with DNA replication by intercalation into DNA molecules, thus inhibiting the biosynthesis of DNA, RNA and protein as well as the induction of the free radicals inside the cell, leading to senescence and cell death by apoptosis or necrosis $[43,44]$. The compounds synthesized have functional groups similar to DOX, which suggests that they may act in a similar manner. Thus, the development of new molecular targets for antitumor therapies is directly correlated to many tumors that are resistant to therapeutic strategies and side effects. The main side effect of DOX is cardiac insufficiency, which is caused by the production of free radicals in the myocardium. In clinical research, chemotherapy resistance has been identified as a serious problem when the concentrations of chemotherapy drugs reach toxic and harmful doses for killing tumors.

\subsection{Lipinski's Rule of Five}

The present study focused on the antiproliferative activity and synthesis of structurally modified galloyl derivatives, but we also explored the bioavailability of the synthesized derivatives, which is of importance for further development of drugs based upon these substances and their analogues. Drug-likeness is a promising paradigm to identify a balance that influences the pharmacodynamic and pharmacokinetic properties of a compound that ultimately optimizes its absorption, distribution, metabolism and excretion (ADME) in the human body [45].

These parameters were tentatively assessed using theoretical calculations following Lipinski's rule of five, which establishes that the absorption or permeation of an orally administered compound is more likely to be efficient if the drug satisfies the established criteria: molecular weight $(\mathrm{MW}) \leq 500 \mathrm{Da}$, $\log \mathrm{P} \leq 5, \mathrm{H}$-bond donors (HBD) $\leq 5$ and H-bond acceptors (HBA).

Our results (Table 3) revealed that derivatives 2, 4-10, presented lipophilicities less than 5, with values between 0.34 and 1.94. Galloyl hydrazide (3) showed lipophilicity, $\log \mathrm{P}=-0.94$, which is not in violation of Lipinski's rules. To further evaluate the drug-likeness, the rules have spawned many extensions, such as the partition coefficient, $\log \mathrm{P}$ in -0.4 to +5.6 ranges [46]. All derivatives have a number of hydrogen bond acceptors (HBA) $(n-\mathrm{ON}=5-9)$, and their molecular weights were smaller than 500 (184.15> MW < 317.26), which is in agreement with Lipinski's rules. With the exception of the hydrazide 3 , they all have a number of hydrogen bond donors (HBD) $(n-\mathrm{OHNH}=6)$, violating one of the Lipinski's rules. The calculated percent absorption (\%ABS) of all derivatives ranged between $57.95 \%$ and $78.98 \%$, indicating that these compounds have good permeability in the cellular membrane. Other rules include the number of rotatable bonds, indicating the flexibility of the molecule, the volume and the polar surface area. The topological polar surface area (TPSA) is recognized as a good indicator of drug absorption in the intestine (TPSA less than 140 Angstroms squared $\left[\AA^{2}\right]$ ) and blood-brain barrier penetration (TPSA less than $60 \AA^{2}$ ). The compounds exhibit computational TPSA values between 86.99 and $122.37 \AA^{2}$ and have good intestinal absorption except 
$6\left(147.97 \AA^{2}\right)$. However, the derivatives do not have adequate blood-brain barrier penetration, as the TPSA values are more than $60 \AA^{2}$.

The empirical conditions to satisfy Lipinski's rule and to manifest a good oral bioavailability involve a balance between the solubility of a compound and its ability to diffuse passively through the different biological barriers. Compounds with high solubility are more easily metabolized and eliminated from the organism, thus leading to a lower probability of adverse effects and bioaccumulation. The compound 2 ( $\log \mathrm{S}=-0.87$ ) presented good solubility, thus encouraging its use as a precursor to produce new drugs that have better absorption.

Table 3. Lipinski's rule and \%ABS, TPSA, Log S for compounds 2-10.

\begin{tabular}{|c|c|c|c|c|c|c|c|c|}
\hline \multirow[b]{2}{*}{ Comp. } & \multirow[b]{2}{*}{$\% A B S$} & \multirow[b]{2}{*}{$\begin{array}{c}\text { TPSA }^{a} \\
\left(\AA^{2}\right) \\
\end{array}$} & \multicolumn{6}{|c|}{ Lipinski's Parameters } \\
\hline & & & $\begin{array}{c}\mathrm{nHBA}^{a} \\
(\mathrm{nON})\end{array}$ & $\begin{array}{c}\mathrm{nHBD}^{a} \\
(\mathrm{nOHNH}) \\
\end{array}$ & $\log P^{a}$ & $\mathbf{M W}^{a}$ & $\mathrm{n}$ violations ${ }^{a}$ & $\log S^{b}$ \\
\hline 2 & 78.98 & 86.99 & 5 & 3 & 0.85 & 184.15 & 0 & -0.87 \\
\hline 3 & 69.04 & 115.80 & 6 & 6 & -0.94 & 184.15 & 1 & -1.09 \\
\hline 4 & 73.75 & 102.15 & 6 & 4 & 1.84 & 272.26 & 0 & -2.83 \\
\hline 5 & 72.64 & 105.38 & 7 & 4 & 1.94 & 315.33 & 0 & -2.87 \\
\hline 6 & 57.95 & 147.97 & 9 & 4 & 1.80 & 317.26 & 0 & -3.47 \\
\hline 7 & 70.57 & 111.38 & 7 & 4 & 1.89 & 302.29 & 0 & -2.85 \\
\hline 8 & 66.78 & 122.37 & 7 & 5 & 1.36 & 288.26 & 0 & -2.54 \\
\hline 9 & 73.63 & 102.51 & 6 & 4 & 0.34 & 226.21 & 0 & -2.10 \\
\hline 10 & 74.63 & 99.61 & 6 & 3 & 1.27 & 240.24 & 0 & -3.07 \\
\hline
\end{tabular}

\section{Experimental Section}

\subsection{Chemistry}

\subsubsection{General}

${ }^{1} \mathrm{H}$ - and ${ }^{13} \mathrm{C}-\mathrm{NMR}$ spectra were recorded at $300 \mathrm{MHz}$ and $75 \mathrm{MHz}$, respectively, using a model Mercury plus BB spectrometer (Varian, Palo Alto, CA, USA). Mass spectra (MS) were recorded in a Focus-DSQ II spectrometer (Thermoelectron Corporation, Austin, TX, USA). IR spectra were recorded on a model MB-100 spectrometer (BOMEM, Quebec, CA, USA). For TLC, precoated plates (silica gel 60 G254, Macherey-Nagel, Duren, GER) were used. All reagents were purchased from commercial suppliers.

\subsubsection{Galloyl hydrazide (3)}

Briefly, $80 \%$ hydrazine hydrate $(1.8 \mathrm{~mL}, 48.2 \mathrm{mmol})$ was added to a solution of methyl gallate (2) (2.5 g, $2.97 \mathrm{mmol})$ that was previously prepared by esterification of commercial gallic acid (1) in ethanol $(30 \mathrm{~mL})$. This mixture was heated at reflux for $60 \mathrm{~h}$, when TLC analysis indicated the end of the reaction. Then, the media was poured on ice, and the resulting precipitate was filtered, affording 
the title compound $3(1.85 \mathrm{~g}, 74 \%)$ as pale white powder, mp $164-167{ }^{\circ} \mathrm{C}(\mathrm{MeOH}) ; \mathrm{mp} 167{ }^{\circ} \mathrm{C}[32]$; IR (KBr) V $v_{\max }\left(\mathrm{cm}^{-1}\right): 3365-3284(\mathrm{O}-\mathrm{H}, \mathrm{N}-\mathrm{H}), 1623(\mathrm{C}=\mathrm{O}), 1509-1303(\mathrm{C}=\mathrm{C}), 1260(\mathrm{C}-\mathrm{O}) ;{ }^{1} \mathrm{H}-\mathrm{NMR}$ (DMSO-d6): $\delta_{\mathrm{H}} 6.77(\mathrm{~s}, 2 \mathrm{H}) ; 8.59(\mathrm{NH}) ; 9.32(\mathrm{OH}) .{ }^{13} \mathrm{C}-\mathrm{NMR}$ (DMSO-d6): $\delta_{\mathrm{c}} 106.5,123.9,136.2$, 145.4, 166.4. MS m/z (\%): $185\left(\mathrm{MH}^{+}, 12\right), 153(100), 126(42)$.

\subsubsection{General Procedure for the Preparation of $N^{\prime}$-(Substituted)-arylidene galloyl hydrazides 4-8}

A solution of galloyl hydrazide $(3)(0.28 \mathrm{~g}, 1 \mathrm{mmol})$ in water $(10 \mathrm{~mL})$ containing two drops of conc. $\mathrm{H}_{2} \mathrm{SO}_{4}$ was heated at reflux for $0.5 \mathrm{~h}$ until complete dissolution. Then, aromatic aldehydes (benzaldehyde, 4- $N$-dimethylaminobenzaldehyde, 4-nitrobenzaldehyde, 4-methoxybenzaldehyde and 4-hydroxybenzaldehyde, $1.5 \mathrm{mmol})$ in EtOH ( $3 \mathrm{~mL})$ were added to the solution, which was then heated at reflux for $48 \mathrm{~h}$. The mixtures were poured into cold water and neutralized with $10 \%$ aqueous $\mathrm{NaHCO}_{3}$. The precipitates were collected by filtration, recrystallized and dried, yielding the compounds $\mathbf{4}-\mathbf{8}$ in $74 \%-83 \%$ yields.

$N^{\prime}$-(Benzylidene)galloyl hydrazide (4). White powder (0.20 g, 71\%), mp 170-173 ${ }^{\circ} \mathrm{C}(\mathrm{MeOH}) ; \mathrm{mp}$ 170-172 ${ }^{\circ} \mathrm{C}$ [32]; IR (KBr) v $v_{\max }\left(\mathrm{cm}^{-1}\right)$ : 3362-3270 (O-H, N-H), $1630(\mathrm{C}=\mathrm{O}), 1518(\mathrm{C}=\mathrm{C}), 1264(\mathrm{C}-\mathrm{O})$; ${ }^{1} \mathrm{H}-\mathrm{NMR}(\mathrm{CD} 3 \mathrm{OD}): \delta_{\mathrm{H}} 7.30-7.68(5 \mathrm{H}, \mathrm{m}), 7.70(2 \mathrm{H}, \mathrm{s}), 8.65\left(1 \mathrm{H}, \mathrm{s}, \mathrm{N}^{\prime}=\mathrm{CH}\right) .{ }^{13} \mathrm{C}-\mathrm{NMR}\left(\mathrm{CD}_{3} \mathrm{OD}\right): \delta_{\mathrm{C}}$ $115.4,126.3,128.7,128.8,131.0,133.9,140.4,145.2,148.7,162.5 . \mathrm{MS} m / z(\%): 272\left(\mathrm{MH}^{+}, 8\right), 153$ (100), $126(30)$.

$N^{\prime}$-(4-Dimethylaminobenzylidene)galloyl hydrazide (5). White powder, $(0.22 \mathrm{~g}, 78 \%) \mathrm{mp} 174-178{ }^{\circ} \mathrm{C}$ $(\mathrm{MeOH}) ; \mathrm{mp} 175-178{ }^{\circ} \mathrm{C}$ [32]; IR (KBr) $v_{\max }\left(\mathrm{cm}^{-1}\right): 3325(\mathrm{O}-\mathrm{H}, \mathrm{N}-\mathrm{H}), 1661(\mathrm{C}=\mathrm{O}), 1520(\mathrm{C}=\mathrm{C})$, 1264 (C-O); ${ }^{1} \mathrm{H}-\mathrm{NMR}\left(\mathrm{CD}_{3} \mathrm{OD}\right): \delta_{\mathrm{H}} 3.03(6 \mathrm{H}, \mathrm{s}), 6.93(2 \mathrm{H}, \mathrm{d}, J=8.7 \mathrm{~Hz}), 7.68(2 \mathrm{H}, \mathrm{s}), 7.78$ (2H, d, $J=8.7 \mathrm{~Hz}), 8.36\left(1 \mathrm{H}, \mathrm{s}, \mathrm{N}^{\prime}=\mathrm{CH}\right) .{ }^{13} \mathrm{C}-\mathrm{NMR}\left(\mathrm{CD}_{3} \mathrm{OD}\right): \delta_{\mathrm{C}} 40.3,111.9,114.1,125.9,129.8,130.4$, 141.4, 146.2, 149.4, 151.2, 162.6. MS m/z (\%): $315\left(\mathrm{MH}^{+}, 12\right), 153$ (100), $126(33)$.

$N^{\prime}$-(4-Nitrobenzylidene)galloyl hydrazide (6). Pale yellow powder $(0.24 \mathrm{~g}, 83 \%) ; \mathrm{mp} 171-174{ }^{\circ} \mathrm{C}$ $(\mathrm{MeOH}) ; \mathrm{mp} 171-172{ }^{\circ} \mathrm{C}$ [32]; IR (KBr) $v_{\max }\left(\mathrm{cm}^{-1}\right)$ : 3422-3280 (O-H, N-H), $1665(\mathrm{C}=\mathrm{O}), 1520$ $(\mathrm{C}=\mathrm{C}), 1264(\mathrm{C}-\mathrm{O}) ;{ }^{1} \mathrm{H}-\mathrm{NMR}\left(\mathrm{CD}_{3} \mathrm{OD}\right): \delta_{\mathrm{H}} 6.98(2 \mathrm{H}, \mathrm{s}), 7.94(2 \mathrm{H}, \mathrm{d}, J=8.5 \mathrm{~Hz}), 7.28(2 \mathrm{H}, \mathrm{d}, J=8.5 \mathrm{~Hz})$, $8.49\left(1 \mathrm{H}, \mathrm{s}, \mathrm{N}^{\prime}=\mathrm{CH}\right), 9.19(\mathrm{OH}, \mathrm{NH}) .{ }^{13} \mathrm{C}-\mathrm{NMR}\left(\mathrm{CD}_{3} \mathrm{OD}\right): \delta_{\mathrm{c}} 116.3,122.8,124.1,127.8,137.3,141.0$, 143.9, 145.6, 147.6, 163.4; MS m/z (\%): $317\left(\mathrm{MH}^{+}, 10\right), 153$ (100), $126(21)$.

$N^{\prime}$-(4-Methoxybenzylidene)galloyl hydrazide (7). Pale white powder (0,23 g, 80\%), mp 170-172 ${ }^{\circ} \mathrm{C}$ $(\mathrm{MeOH}) ; \mathrm{mp} 171-173{ }^{\circ} \mathrm{C}$ [32]; IR (KBr) $v_{\max }\left(\mathrm{cm}^{-1}\right): 3410-3260(\mathrm{O}-\mathrm{H}, \mathrm{N}-\mathrm{H}), 1668(\mathrm{C}=\mathrm{O}), 1520$ $(\mathrm{C}=\mathrm{C}), 1262(\mathrm{C}-\mathrm{O}) ;{ }^{1} \mathrm{H}-\mathrm{NMR}\left(\mathrm{CD}_{3} \mathrm{OD}\right): \delta_{\mathrm{H}} 3.87\left(3 \mathrm{H}, \mathrm{s}, \mathrm{OCH}_{3}\right), 7.00(2 \mathrm{H}, \mathrm{s}), 7.70(2 \mathrm{H}, \mathrm{d}, J=8.3 \mathrm{~Hz})$, $6.80(2 \mathrm{H}, \mathrm{d}, J=8.3 \mathrm{~Hz}), 8.58\left(1 \mathrm{H}, \mathrm{s}, \mathrm{N}^{\prime}=\mathrm{CH}\right) .{ }^{13} \mathrm{C}-\mathrm{NMR}\left(\mathrm{CD}_{3} \mathrm{OD}\right): \delta \mathrm{c} 55.6,110.2,114.4,126.5$, 128.6, 130.0, 136.8, 145.5, 146.6, 160.5, 161.6; MS m/z (\%): $302\left(\mathrm{MH}^{+}, 31\right), 153$ (100), 126 (17).

$N^{\prime}$-(4-Hydroxybenzylidene)galloyl hydrazide (8). White powder $(0,20 \mathrm{~g}, 78 \%), \mathrm{mp} 170-173{ }^{\circ} \mathrm{C}$ $(\mathrm{MeOH}) ; \mathrm{mp} 172-174{ }^{\circ} \mathrm{C}$ [32]; IR (KBr) $v_{\max }\left(\mathrm{cm}^{-1}\right): 3418-3266(\mathrm{O}-\mathrm{H}, \mathrm{N}-\mathrm{H}), 1668(\mathrm{C}=\mathrm{O}), 1571$ $(\mathrm{C}=\mathrm{C}), 1260(\mathrm{C}-\mathrm{O}) ;{ }^{1} \mathrm{H}-\mathrm{NMR}\left(\mathrm{CD}_{3} \mathrm{OD}\right): \delta_{\mathrm{H}} 7.12(2 \mathrm{H}, \mathrm{s}), 7.34(2 \mathrm{H}, \mathrm{d}, J=7.8 \mathrm{~Hz}), 6.60(2 \mathrm{H}, \mathrm{d}, J=7.8$ $\mathrm{Hz}), 8.66\left(1 \mathrm{H}, \mathrm{s}, \mathrm{N}^{\prime}=\mathrm{CH}\right) .{ }^{13} \mathrm{C}-\mathrm{NMR}\left(\mathrm{CD}_{3} \mathrm{OD}\right): \delta_{\mathrm{C}} 115.6,114.8,125.5,128.7,132.0,136.8,147.5$, 147.6, 158.5, 160.6; MS m/z (\%): $288\left(\mathrm{MH}^{+}, 18\right), 153$ (100), 126 (44). 


\subsubsection{Galloyl-2-thioxo-1,3,4-oxadiazole (9)}

Carbon disulfide $(0.8 \mathrm{~mL}, 5 \mathrm{mmol})$ and potassium hydroxide $(0,213 \mathrm{~g}, 1 \mathrm{mmol})$ were added to a solution of galloyl hydrazide $(3)(0.456 \mathrm{~g}, 1 \mathrm{mmol})$ in $\mathrm{EtOH}(10 \mathrm{~mL})$ at $0{ }^{\circ} \mathrm{C}$. The resulting solution was heated at reflux for $48 \mathrm{~h}$. The solvent was evaporated, and the residue was dissolved in water and acidified with a dilute solution of $\mathrm{HCl}$. The solid obtained was filtered and recrystallized to give the title compound $9(0.36 \mathrm{~g}, 80 \%)$ as a white powder, mp $168-170{ }^{\circ} \mathrm{C}(\mathrm{MeOH})$; IR $(\mathrm{KBr}) v_{\max }\left(\mathrm{cm}^{-1}\right)$ : 3370-3280 (O-H), 1595-1430 (C=C), 1245 (C-S), 1168 (C-O-C); ${ }^{1} \mathrm{H}-\mathrm{NMR}\left(\mathrm{CD}_{3} \mathrm{OD}\right): \delta_{\mathrm{H}} 6.82(2 \mathrm{H}, \mathrm{s})$, $9.05(\mathrm{OH}, \mathrm{NH}) ;{ }^{13} \mathrm{C}-\mathrm{NMR}\left(\mathrm{CD}_{3} \mathrm{OD}\right): \delta_{\mathrm{C}} 105.0,112.0,137.6,146.5,161.1,176.9 . \mathrm{MS} \mathrm{m} / \mathrm{z}(\%): 226$ $\left(\mathrm{MH}^{+}, 12\right), 150$ (100), 77 (28).

\subsubsection{Galloyl-2-methylthio-1,3,4-oxadiazole (10)}

To a solution of galloyl-2-thioxo-1,3,4-oxadiazole (9) $(0.20 \mathrm{~g}, 0.6 \mathrm{mmol})$ in anhydrous THF (10 $\mathrm{mL})$ was to added $\mathrm{K}_{2} \mathrm{CO}_{3}(0.14 \mathrm{~g}, 0.6 \mathrm{mmol})$. The resulting solution was stirred at room temperature for $1 \mathrm{~h}$. Methyl iodide $(0.19 \mathrm{~mL}, 0.8 \mathrm{mmol})$ was then added, and the mixture was stirred for an additional $48 \mathrm{~h}$. The solvent was removed, and the residue obtained was crystallized to give the title compound $\mathbf{1 0}$ $(0.1192 \mathrm{~g}, 60 \%)$, as a brown powder, mp $166-168{ }^{\circ} \mathrm{C}(\mathrm{MeOH})$; IR $(\mathrm{KBr}) v_{\max }\left(\mathrm{cm}^{-1}\right): 3376(\mathrm{O}-\mathrm{H}$, $\mathrm{N}-\mathrm{H}), 1668(\mathrm{C}=\mathrm{O}), 1565-1430(\mathrm{C}=\mathrm{C}), 1170(\mathrm{C}-\mathrm{O}-\mathrm{C}), 720(\mathrm{C}-\mathrm{S}-\mathrm{C}) ;{ }^{1} \mathrm{H}-\mathrm{NMR}\left(\mathrm{CD}_{3} \mathrm{OD}\right): \delta_{\mathrm{H}} 2.80(3 \mathrm{H}$, $\left.\mathrm{s}, \mathrm{SCH}_{3}\right) ; 7.00(2 \mathrm{H}, \mathrm{s}) ; 9.62(\mathrm{OH}) .{ }^{13} \mathrm{C}-\mathrm{NMR}\left(\mathrm{CD}_{3} \mathrm{OD}\right): \delta_{\mathrm{C}} 16.2,110.2,112.4,136.6,146.8,162.2$, 160.4; MS $m / z(\%): 240\left(\mathrm{MH}^{+}, 8\right), 150$ (100), 91 (28).

\subsection{Anticancer Assay in Vitro}

The synthesized compounds were assessed in the following ten human tumor cell lines from various tissues kindly provide by the National Cancer Institute (Frederick, MD, USA): U251 (glioma, CNS), MCF-7 (breast), NCI-ADR/RES (breast expressing the multiple drug resistance phenotype), 786-0 (renal), NCI-H460 (lung, non-small cells), PC-3 (prostate), OVCAR-3 (ovarian), HT-29 (colon), K-562 (leukemia) and HaCaT (keratinocytes). Stock cultures were grown in media containing $5 \mathrm{~mL}$ of RPMI 1640 (Gibco BRL) supplemented with 5\% fetal bovine serum. Gentamicin (50 mg/mL) was added to the experimental cultures. Cells in 96-well plates $(100 \mu \mathrm{L}$ cells/well) were exposed to sample concentrations in DMSO/RPMI $(0.25,2.5,25$, and $250 \mu \mathrm{g} / \mathrm{mL})$ at $37{ }^{\circ} \mathrm{C}$ and $5 \% \mathrm{CO}_{2}$ for $48 \mathrm{~h}$. The final DMSO concentration did not affect cell viability. Next, cells were fixed with $50 \%$ trichloroacetic acid, and cell proliferation was determined by spectrophotometric quantification (540 nm) of cellular protein content employing the sulforhodamine B assay [49]. Doxorubicin $(0.025-25 \mu \mathrm{g} / \mathrm{mL})$ was used as a positive control. Three measurements were obtained: first at time point zero $\left(\mathrm{T}_{0}\right.$, at the beginning of incubation) and then $48 \mathrm{~h}$ post-incubation for both the compound-free (C) and tested (T) cells. Cell proliferation was determined using the equation $100 \times\left[\left(\mathrm{T}-\mathrm{T}_{0}\right) / \mathrm{C}-\mathrm{T}_{0}\right]$. A cytostatic effect was observed when $\mathrm{T} \geq \mathrm{T}_{0}$, while a cytocidal effect occurred when $\mathrm{T}<\mathrm{T}_{0}$. The experiments were performed in triplicate. 


\subsection{In Silico Study}

An in silico computational study of the synthesized compounds $\mathbf{2}-\mathbf{1 0}$ was performed to determine Lipinski's rules, topological polar surface area (TPSA) and percentage of absorption (\%ABS). Calculations were performed using Molinspiration online property calculation toolkit software [47] and OSIRIS property explorer software [48]. The percentage of absorption was estimated using the following equation: $\% \mathrm{ABS}=109-[0.345 \times \mathrm{TPSA}]$. Lipinski's rule states that an orally active drug generally has no more than one violation of the following criteria [50]:

(I) hydrogen bond donors $\leq 5$ ( $\mathrm{OH}$ and $\mathrm{NH}$ groups);

(II) hydrogen bond acceptors $\leq 10$ ( $\mathrm{N}$ and $\mathrm{O}$ atoms);

(III) molecular weight $<500$;

(IV) calculated $\log \mathrm{P}<5$.

\section{Conclusions}

The results suggest that synthetic derivatives of $N^{\prime}$-(substituted)-arylidenegalloyl hydrazide do not have a very strong synergistic effect in the inhibition of cancer cell proliferation compared with methyl gallate (2), galloyl hydrazide (3) and 1,3,4-oxadiazolyl derivatives 9 and 10. These compounds showed higher inhibition effect against ovarian (OVCAR-3) cells. Computational drug-likeness and TPSA calculations revealed that the compounds show good intestinal absorption. Finally, the in silico study identified these derivatives as potential new drug candidates. More detailed studies with other models, such in vivo assays, are essential for the characterization of these derivatives as anticancer agents.

\section{Acknowledgments}

We are grateful to Fundect and CAPES fellowships for financial support (ASNF and MMS). The authors are grateful Maria Helena Sarragiotto (Departamento de Química-UEM, Maringá-PR) for technical support. Maria do Carmo Vieira in acquisition materials.

\section{Author Contributions}

ASNF, MMS, TSD and MC designed the study, synthesis of compounds and in silico study. MAF and JEC participated in the antiproliferative assay. MCV helped conduct the literature review and in implementation of the study.

\section{Conflicts of Interest}

The authors declare that they have no competing interests.

\section{References}

1. Golumbic, C.; Mattill, H.A. The antioxidant properties of gallic acid and allied compounds. J. Am. Chem. Soc. 1942, 19, 144-145. 
2. Kim, D.O.; Lee, K.W.; Lee, H.J.; Lee, C.Y. Vitamin C equivalent antioxidant capacity of phenolic phytochemicals. J. Agric. Food Chem. 2002, 50, 3713-3717.

3. Kroes, B.H.; van den Berg, A.J.J.; Quarles van Ufford, H.C.; van Dijk, H.; Labadie, R.P. Anti-inflammatory activity of gallic acid. Planta Med. 1992, 58, 499-504.

4. Gichner, T. Two types of antimutagenic effects of gallic and tannic acids towards N-nitrosocompounds-induced mutagenicity in the Ames Salmonella assay. Folia Microbiol. 1987, 32, 55-62.

5. Mirvish, S.S.; Cardesa, A.; Wallcave, L.; Shubik, P. Induction of mouse lung adenomas by amines or ureas plus nitrite and by N-nitroso compounds: Effect of ascorbate, gallic acid, thiocyanate and caffeine. J. Natl. Cancer Inst. 1975, 55, 633-666.

6. Inoue, M.; Suzuki, R.; Sakaguchi, N.; Li, Z.; Takeda, T.; Ogihara, Y.; Jiang, B.; Chen, Y. Role of reactive oxygen species in gallic acid-induced apoptosis. Biol. Pharm. Bull. 1995, 18, 1526-1530.

7. Yoshioka, K.; Kataoka, T.; Hayashi, T.; Hasegawa, M.; Ishi, Y.; Hibasami, H. Induction of apoptosis by gallic acid in human stomach cancer KATO III and colon adenocarcinoma COLO205 cell lines. Oncol. Rep. 2000, 6, 1221-1223.

8. Hsu, C.; Lo, W.; Yen, G. Gallic acid induces apoptosis in 3T3-L1 pre-adipocytes via a Fas- and mitochondrial-mediated pathway. J. Agric. Food Chem. 2007, 55, 7359-7365.

9. Kaur, M.; Velmurugan, B.; Rajamanickam, S.; Agarwal, R.; Agarwal, C. Gallic acid, an active constituent of grape seed extract, exhibits antiproliferative, pro apoptotic and anti-tumorigenic effects against prostate carcinoma xenograft growth in nude mice. Pharm. Res. 2009, 26, 2133-2140.

10. You, B.R.; Park, W.H. Gallic acid induced lung cancer cell death is related to glutathione depletion as well as reactive oxygen species increase. Toxicol. In Vitro 2010, 24, 1356-1362.

11. You, B.R.; Moon, H.J.; Han, Y.H.; Park, W.H. Gallic acid inhibits the growth of HeLa cervical cancer cells via apoptosis and/or necrosis. Food Chem. Toxicol. 2010, 48, 1334-1340.

12. Lu, Y.; Jiang, F.; Jiang, H.; Wu, K.; Zheng, X.; Cai, Y.; Katakowski, M.; Chopp, M.; To, S.T. Gallic acid suppresses cell viability, proliferation, invasion and angiogenesis in human glioma cells. Eur. J. Pharmacol. 2010, 641, 102-107.

13. Madlener, S.; Illmer, C.; Horvath, Z.; Saiko, P.; Losert, A.; Herbacek, I.; Grusch, M.; Elford, H.L.; Krupitza, G.; Bernhaus, A.; et al. Gallic acid inhibits ribonucleotide reductase and cyclooxygenases in human HL-60 promyelocytic leukemia cells. Cancer Lett. 2007, 245, 156-162.

14. Bernhaus, A.; Fritzer-Szekeres, M.; Grusch, M.; Saiko, P.; Krupitza, G.; Venkateswarlu, G.; Trimurtulu, G.; Jaeger, W.; Szekeres, T. Digalloylresveratrol, a new phenolic acid derivative induces apoptosis and cell cycle arrest in human HT-29 colon cancer cells. Cancer Lett. 2009, 274, 299-304.

15. Chia, Y.C.; Rajbanshi, R.; Calhoun, C.; Chiu, R.H. Anti-neoplastic effects of gallic acid, a major component of Toona sinensis leaf extract, on oral squamous carcinoma cells. Molecules 2010, 15, $8377-8389$.

16. Horvath, Z.; Saiko, P.; Illmer, C.; Madlener, S.; Hoechtl, T.; Bauer, W.; Erker, T.; Jaeger, W.; Fritzer-Szekeres, M.; Szekeres, T. Synergistic action of resveratrol, an ingredient of wine, with Ara-C and tiazofurin in HL-60 human promyelocytic leukemia cells. Exp. Hematol. 2005, 33, $329-335$. 
17. Liang, Y.C.; Tsai, S.; Chen, L.; Lin-Shiau, L.; Lin, J. Resveratrol-induced G2 arrest through the inhibition of CDK7 and p34CDC2 kinases in colon carcinoma HT29 cells. Biochem. Pharmacol. 2003, 65, 1053-1060.

18. Lee, N.Y. Development of Gallic Acid-Conjugated Linoleic Acid Ester as Novel Functional Materials and Its Biological Activity. Ph.D. Thesis, Chonbuk National University, Jeonju, Korea, 2007.

19. Lee, H.; Kwon, Y.; Lee, J.H.; Kim, J.; Shin, M.K.; Kim, S.H.; Bae, H. Methyl gallate exhibits potent antitumor activities by inhibiting tumor infiltration of $\mathrm{CD} 4{ }^{+} \mathrm{CD} 25^{+}$regulatory $\mathrm{T}$ cells. J. Immunol. 2010, 185, 6698-6705.

20. Wacher, V.J. Use of Gallic Acid Esters to Increase Bioavailability of Orally Administered Pharmaceutical Compounds. Ph.D. Thesis, University of California, San Francisco, CA, USA, 2001.

21. Spickenreither, M.; Braun, S.; Bernhardt, G.; Dove, S.; Buschauer, A. Novel 6-O-acylated vitamin $\mathrm{C}$ derivatives as hyaluronidase inhibitors with selectivity for bacterial lyases. Bioorg. Med. Chem. Lett. 2006, 16, 5313-5316.

22. Isoyama, T.; Thwaites, D.; Selzer, M.G.; Carey, R.I.; Barbucci, R.; Lokeshwar, V.B. Differential selectivity of hyaluronidase inhibitors toward acidic and basic hyaluronidases. Glycobiology 2006, $16,11-21$.

23. Kohen, R.; Nyska, A. Oxidation of biological systems: Oxidative stress phenomena, antioxidants, redox reaction, and methods for their quantification. Toxicol. Pathol. 2002, 30, 620-650.

24. Salahuddin, M.A.; Shaharyar, M. Synthesis, Characterization, and In Vitro Anticancer Evaluation of Novel 2,5-Disubstituted 1,3,4-Oxadiazole Analogue. BioMed Res. Int. 2014, 2014, 1-14.

25. Kothayer, H.; Elshanawani, A.A.; Abu Kull, M.E.; El-Sabbagh, O.I.; Shekhar, M.P.; Brancale, A; Jones, A.T.; Westwell, A.D. Design, synthesis and in vitro anticancer evaluation of 4,6-diamino-1,3,5-triazine-2-carbohydrazides and -carboxamides. Bioorg. Med. Chem. Lett. 2013, $23,6886-6889$.

26. Rodrigues, J.R.; Charris, J.; Camacho, J.; Barazarte, A.; Gamboa, N.; Antunes, F. Cytotoxic effects of $N^{\prime}$-formyl-2-(5-nitrothiophen-2-yl)benzothiazole-6-carbohydrazide in human breast tumor cells by induction of oxidative stress. Anticancer Res. 2012, 32, 2721-2726.

27. Ali, M.A.; Shaharyar, M. Oxadiazole mannich bases: Synthesis and antimycobacterial activity. Bioorg. Med. Chem. Lett. 2007, 17, 3314-3316.

28. Formagio, A.S.N.; Tonin, L.T.D.; Foglio, M.A.; Madjarof, C.; de Carvalho, J.E.; da Costa, W.F.; Cardoso, F.P.; Sarragiotto, M.H. Synthesis and antitumoral activity of novel 3-(2-substituted1,3,4-oxadiazol-5-yl) and 3-(5-substituted-1,2,4-triazol-3-yl) $\beta$-carboline derivatives. Bioorg. Med. Chem. Lett. 2008, 16, 9660-9667.

29. Savariz, F.C.; Formagio, A.S.N.; Barbosa, V.A.; Foglio, M.A.; de Carvalho, J.E.; Duarte, M.C.T.; Filho, B.P.D.; Sarragiotto, M.H. Synthesis, Antitumor and Antimicrobial Activity of Novel 1-Substituted Phenyl-3-[3-alkylamino(methyl)-2-thioxo-1,3,4-oxadiazol-5-yl] $\beta$-Carboline Derivatives. J. Braz. Chem. Soc. 2010, 21, 288-298.

30. Barbosa, V.A.; Formagio, A.S.N.; Savariz, F.C.; Foglio, M.A.; Spindola, H.M.; Carvalho, J.E.; Meyer, E.; Sarragiotto, M.H. Synthesis and antitumor activity of $\beta$-carboline 3-(substitutedcarbohydrazide) derivatives. Bioorg. Med. Chem. 2011, 19, 6400-6408. 
31. Vogel, A.I. A Textbook of Practical Organic Chemistry, 3rd ed.; Wiley: New York, NY, USA, 1957; pp. 538-539.

32. Ilango, K.; Arunkumar, S. Synthesis, antimicrobial and antitubercular activities of some novel trihydroxy benzamido azetidin-2-one derivatives. Trop. J. Pharm. Res. 2011, 10, 219-229.

33. Hsieh, T.J.; Liu, T.Z.; Chi, Y.C.; Chern, C.L.; Lu, F.J.; Chuang, M.C.; Mau, S.Y.; Chen, S.H.; Syu, Y.H.; Chen, C.H. Protective effect of methyl gallate from Toona sinensis (Meliaceae) against hydrogen peroxide-induced oxidative stress and DNA damage in MDCK cells. Food Chem. Toxicol. 2004, 42, 843-850.

34. Choi, J.G.; Kang, O.H.; Lee, Y.S.; Oh, Y.C.; Chae, H.S.; Jang, H.J.; Shin, D.W.; Kwon, D.Y. Antibacterial activity of methyl gallate isolated from Galla Rhois or carvacrol combined with nalidixic acid against nalidixic acid resistant bacteria. Molecules 2009, 14, 1773-1780.

35. Kang, M.S.; Jang, H.S.; Oh, J.S.; Yang, K.H.; Choi, N.K.; Lim, H.S.; Kim, S.M. Effects of methyl gallate and gallic acid on the production of inflammatory mediators interleukin- 6 and interleukin-8 by oral epithelial cells stimulated with Fusobacterium nucleatum. J. Microbiol. 2009, 47, 760-767.

36. Kang, M.S.; Oh, J.S.; Kang, I.C.; Hong, S.J.; Choi, C.H. Inhibitory effect of methyl gallate and gallic acid on oral bacteria. J. Microbiol. 2008, 46, 744-750.

37. Lee, S.H.; Kim, J.K.; Kim, D.W.; Hwang, H.S.; Eum, W.S.; Park, J.; Han, K.H.; Oh, J.S.; Choi, S.Y. Antitumor activity of methyl gallate by inhibition of focal adhesion formation and Akt phosphorylation in glioma cells. Biochim. Biophys. Acta 2013, 1830, 4017-4029.

38. Tsuruo, T.; Naito, M.; Tomida, A.; Fujita, N.; Mashima, T.; Sakamoto, H.; Haga, N. Molecular targeting therapy of cancer: drug resistance, apoptosis and survival signal. Cancer Sci. 2003, 94, $15-21$.

39. Hui, R.C.; Francis, R.E.; Guest, S.K.; Costa J.R.; Gomes, A.R.; Myatt, S.S.; Brosens, J.J; Lam, E.W.F. Doxorubicinactivates FOXO3a to induce the expression of multidrug resistance gene ABCB1(MDR1) in K562 leukemic cells. Mol. Cancer Ther. 2008, 7, 670-678.

40. Harisi, R.; Dudas, J.; Nagy-Olah, J.; Timar, F.; Szendroi, M.; Jeney, A. Extracellular matrixinduces doxorubicin-resistance in human osteosarcoma cells by suppression of p53 function. Cancer Biol. Ther. 2007, 6, 1240-1246.

41. Ferreira, M.J.; Duarte, N.; Gyemant, N.; Radics, R.; Cherepnev, G.; Varga, A.; Molnár, J. Inter-action between doxorubicin and the resistance modifier stilbene on multidrugresistant mouse lymphoma and human breast cancer cells. Anticancer Res. 2006, 26, 3541-3546.

42. Song, X.; Liu, X.; Chi, W.; Liu, Y.; Wei, L.; Wang, X.; Jinming, Y. Hypoxia-induced resistance tocisplatin and doxorubicin in non-small cell lung cancer is inhibited by silencingof HIF-1alpha gene. Cancer Chemother. Pharmacol. 2006, 58, 776-784.

43. Biing, J.T.; Yang, Y.F.; Liu, H.S.; Ye, C.T.; Chao, C.F. The induction of multidrug resistancein human cervical carcinoma cell lines by estrogenic hormones. Proc. Natl. Sci. Counc. Repub. China Part B: Life Sci. 1994, 18, 64-70.

44. Turner, J.G.; Sullivan, D.M. CRM1-mediated nuclear export of proteins and drug resistance in cancer. Curr. Med. Chem. 2008, 15, 2648-2655.

45. Vistoli, G.; Pedretti, A.; Testa, B. Assessing drug-likeness e what are we missing? Drug Discov. Today 2008, 13, 285-294. 
46. Ghose, A.K.; Viswanadhan, V.N.; Wendoloski, J.J. A Knowledge-Based Approach in Designing Combinatorial or Medicinal Chemistry Libraries for Drug Discovery. J. Comb. Chem. 1999, 1, 55-68.

47. Ertl, P. Calculation of Molecular Properties and Bioactivity Score. Available online: http://www.molinspiration.com (accessed on 2 November 2014).

48. Sander, T. Molecular Property Explorer. Available online: http://www.organic-chemistry.org/prog/peo (accessed on 2 November 2014).

49. Monks, A.; Scudiero, D.; Skehan, P.; Shoemaker, R.; Paull, K.; Vistica, D.; Hose, C.; Langlet, J.; Cronise, P.; Vaigro-Wolff, A.; et al. Feasibility of a high-flux anticancer drug screen using diverse panel of cultured human tumor cell lines. J. Natl. Cancer Inst. 1991, 83, 757-766.

50. Zhao, M.; Bi, L.; Wang, W.; Wang, C.; Baudy-Floc'h, M.; Ju, J.; Peng, S. Synthesis and cytotoxic activities of $\beta$-carboline amino acid ester conjugates. Bioorg. Med. Chem. 2006, 14, 6998-7010.

Sample Availability: Samples of the compounds $\mathbf{2 - 1 0}$ are available from the authors.

(C) 2015 by the authors; licensee MDPI, Basel, Switzerland. This article is an open access article distributed under the terms and conditions of the Creative Commons Attribution license (http://creativecommons.org/licenses/by/4.0/). 